\title{
Presence of Megaplasmids in Rhizobium tropici and Further Evidence of Differences between the Two $R$. tropici Subtypes
}

\author{
ERIC GENIAUX, MARGARITA FLORES, RAFAEL PALACIOS, AND ESPERANZA MARTINEZ* \\ Departamento de Genética Molecular, Centro de Investigación sobre Fijación de Nitrógeno, \\ Universidad Nacional Autónoma de México, Cuernavaca, Morelos, Mexico
}

\begin{abstract}
Using a modified Eckhardt method, we visualized replicons larger than $1,000 \mathrm{~kb}$ in Rhizobium tropici strains belonging to both subgroup A and subgroup B. The megaplasmid of $R$. tropici CFN299 was characterized. This megaplasmid is different from a cointegrate of various plasmids and from the chromosome. Hybridization of Eckhardt blots of $15 \mathrm{R}$. tropici strains with fragments derived from the megaplasmids of the type strains of subgroups $A$ and $B$ revealed that the megaplasmids are subgroup specific.
\end{abstract}

Rhizobium spp. form nitrogen-fixing nodules on the roots of leguminous plants. In Rhizobium strains plasmids constitute an important part of the genome $(11,18,28)$. Megaplasmids larger than $1,000 \mathrm{~kb}$ have been found in Rhizobium meliloti (32), Rhizobium fredii (20), and Rhizobium galegae strains (24). In Rhizobium species, genes essential for nodule formation and nitrogen fixation are located on plasmids called symbiotic plasmids (pSym) $(12,25)$, and these genes have been shown to be located on megaplasmids in $R$. meliloti $(11,32)$.

Rhizobium tropici strains nodulate Phaseolus vulgaris L. beans and other tropical legumes, including Leucaena sp. trees. Two subgroups, corresponding to type A and type B strains, have been described for this species on the basis of differences in rRNA genes and differences in several other phenotypic characteristics, including resistance to metals and antibiotics and the ability to metabolize certain carbon sources (19). We analyzed 15 previously described (19) $R$. tropici strains, including members of both subgroups, for their plasmids by using a modification (37) of the Eckhardt procedure (4) in which horizontal agarose gels are used (Fig. 1A). A replicon larger than $1,000 \mathrm{~kb}$ that has not been observed previously was found in all of the $R$. tropici strains, as well as in $R$. fredii USDA 191 (13) and $R$. meliloti RCR 2011, but not in Rhizobium loti NZP2037 (3), Rhizobium leguminosarum bv. viciae VF39 (29), R. leguminosarum bv. trifolii USDA 2152, or Rhizobium etli CFN42 (30) (Fig. 2). The nature of the replicon was determined in type A strain CFN299. To verify that this replicon was not a cointegrate of smaller plasmids, the homology between the megaplasmid and smaller plasmids was examined. Each of the smaller plasmids used $(185,225$, and $410 \mathrm{~kb})$ was transferred to an Agrobacterium tumefaciens plasmidless strain (16; this study), purified from it, and used as a probe for the CFN299 plasmid. We observed no homology with any of the plasmids (Fig. 3, lanes 1 to 4). In order to distinguish between a chromosome and a megaplasmid, an Eckhardt blot was hybridized to a 300-bp fragment of the $R$. etli $16 \mathrm{~S}$ rRNA genes (34). No hybridization was detected (Fig. 3, lane 5), indicating that the replicon was different from the chromosome.

When R. tropici CFN299 was cross-mated with Escherichia coli S17 pSup 5011 (35), the CFN299 mutants (which were resistant to $60 \mathrm{mg}$ of kanamycin per liter) were analyzed to

\footnotetext{
* Corresponding author. Mailing address: Departamento de Genética Molecular, Centro de Investigación sobre Fijación de Nitrógeno, Universidad Nacional Autónoma de México, Apartado Postal 565-A, Cuernavaca, Morelos, Mexico. Phone: (73) 1316 97. Fax: (73) 1755 81. Electronic mail address: esperanza@n2.cefini.unam.mx.
}

locate Tn5. Hybridization between pSup 5011 and blotted plasmid patterns revealed that the frequencies of $\operatorname{Tn} 5$ insertion for each replicon were $52 \%$ for the chromosome, $30 \%$ for the megaplasmid, $10 \%$ for the pSym, and $8 \%$ for plasmids a and $\mathrm{b}$. These values are consistent with the estimated molecular weights of the chromosome and the plasmids (17) and clearly show that insertions occurred independently in each replicon.

Eckhardt blots of CFN299 were hybridized to the following different genes related to symbiosis: nifHDK (from pCQ15 [30]), lps (from pCOS309 [2]), exoF (from pEX80 [5]), dctABD (from pRmT105 [7]), and the citrate synthase gene (from pMP7 [27]). Using high-stringency hybridization conditions, we found that only the exoF gene hybridized to the megaplasmid. In $R$. meliloti exoF is also located on a megaplasmid, as are other exo genes (15). Although exopolysaccharidedeficient mutants of $R$. tropici have been described (21), the localization of the exopolysaccharide genes has not been reported previously. Our results suggest that genes for exopolysaccharide production could be harbored in the $R$. tropici megaplasmid. The nifHDK and citrate synthase genes hybridized to pSym, as reported previously (Fig. 3).

To study the structural conservation of these megaplasmids in $R$. tropici strains, fragments of the megaplasmids from strains CFN299 (type A) and CIAT899 (type B) were used as probes. To do this, each megaplasmid was labeled with Tn5$m o b$ and transferred to plasmid-free $A$. tumefaciens strains by using RP4-4 as a helper. The latter was transferred from VF39 SM/PRleVF39c::Tn5-mob/RP4-4 (10). With this procedure, only deleted megaplasmids that were 100 to $450 \mathrm{~kb}$ long were obtained in $A$. tumefaciens transconjugants. These organisms were grown in Luria broth (33) supplemented with rifampin (200 $\mathrm{mg} /$ liter) and neomycin (60 mg/liter). Two agrobacteria, each harboring $450-\mathrm{kb}$ fragments from either CFN299 or CIAT 899 (9), were used as sources of the probes for hybridization to Eckhardt blots (Fig. 1B and C). The CFN299 megaplasmid was structurally conserved in strains BR10043, BR846, BR842, BR836, BR835, and BR833, which belong to the same subgroup (Fig. 1B, lanes 1 to 7 ). Likewise, the CIAT 899 megaplasmid was structurally conserved in strains BR847, BR852, BR857, BR858, and BR859, which belong to the same subgroup (Fig. 1C, lanes 8 to 13). No homology between megaplasmids in members of the two subgroups was found. Therefore, the megaplasmids are subgroup specific.

$R$. tropici is native to South America but has also been isolated from nodules of $P$. vulgaris from acid soils in Kenya (18). Very recently, type A $R$. tropici strains have also been isolated from nodules of $P$. vulgaris plants grown in sandy soils in southwestern France (1). In this ecological study, nodule 
(A)

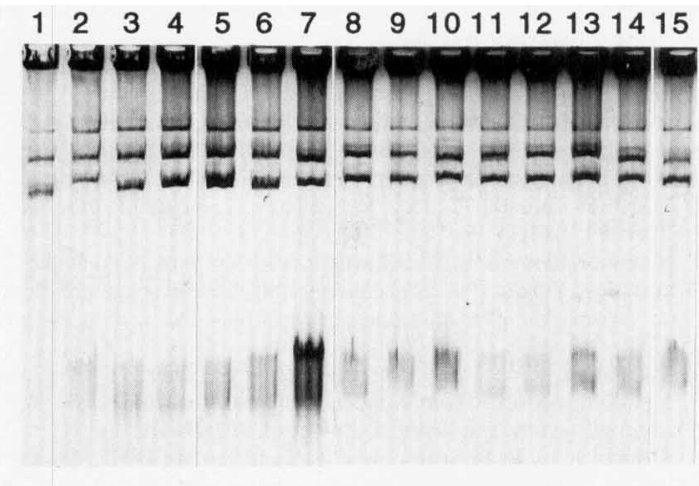

(B)

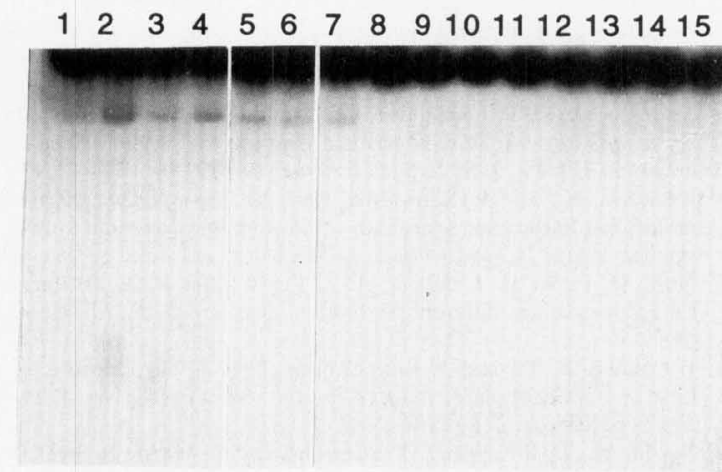

(C)

$\begin{array}{llllllllllllll}1 & 2 & 3 & 4 & 5 & 6 & 7 & 8 & 9 & 10 & 11 & 12 & 13\end{array}$

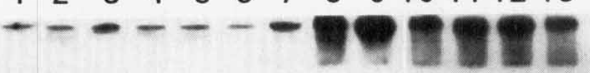

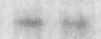

FIG. 1. Plasmid profiles of $R$. tropici strains. Rhizobium strains were grown in liquid PY medium (22) at $30^{\circ} \mathrm{C}$ to an optical density at $620 \mathrm{~nm}$ of approximately 0.3 . The plasmids in freshly grown cultures were visualized on horizontal agarose Eckhardt gels by using a modification of the procedure by Wheatcroft et al. (37). (A) Ethidium bromide-stained Eckhardt gel. (B) Southern blot of the plasmid profiles on nylon filters hybridized as described previously (8) with purified deleted megaplasmid from CFN299 labelled with ${ }^{32} \mathrm{P}$ by nick translation (31). Lane 1, CFN299; lane 2, BR10043; lane 3, BR846; lane 4, BR842; lane 5, BR836; lane 6, BR835; lane 7, BR833; lane 8, CIAT899; lane 9, BR847; lane 10, BR850; lane 11, BR852; lane 12, BR857; lane 13, BR858; lane 14, BR859; lane 15, BR864. (C) Southern blot of the plasmid profiles hybridized with purified deleted CIAT899 megaplasmid as described above. Lane 1, CFN299; lane 2, BR10043; lane 3, BR846; lane 4, BR842; lane 5, BR836; lane 6, BR835; lane 7, BR833; lane 8, CIAT899; lane 9, BR847; lane 10, BR852; lane 11, BR857; lane 12, BR858; lane 13, BR859.

isolates were characterized for their plasmid contents, and in some cases a high-molecular-weight band (like the one described in this paper) was also observed in these strains.

Megaplasmids have sometimes been considered minichromosomes in members of the genus Rhizobiium because they harbor genes that may be important for bacterial survival (6). Furthermore, it has not been possible to remove them from

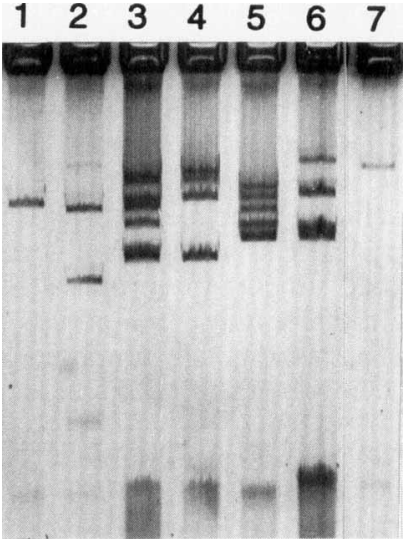

FIG. 2. Plasmid profiles produced as described in the legend to Fig. 1. Lane $1, R$. loti NZP2037; lane 2, $R$. fredii USDA 191; lane $3, R$. leguminosarum bv viciae VF39; lane $4, R$. leguminosanum bv. trifolii USDA 2152 ; lane $5, R$. etli CFN42; lane 6, R. tropici CFN299; lane 7, R. meliloti RCR 2011.

bacteria in the laboratory. Megaplasmids have been found to be more difficult to transfer from one bacterium to another than smaller plasmids are (as we observed). In taxonomic and systematic studies it has been recommended that bacterial species should be established on the basis of chromosomal characteristics. The contribution of megaplasmids to the definition of genetically significant groups should not be denied, in view of the large amount of DNA contained in megaplasmids and in view of the relative stability of megaplasmids in bacterial lineages.

DNA-DNA hybridization experiments revealed that the level of homology was relatively low (36\%) when type A and type B $R$. tropici strains were compared in two independent studies $(14,17)$. Other workers have pointed out additional differences between the two types (23). Type B strains produce chlorosis in bean plants under certain growth conditions, while type A strains do not (26). A PCR analysis of repetitive se-

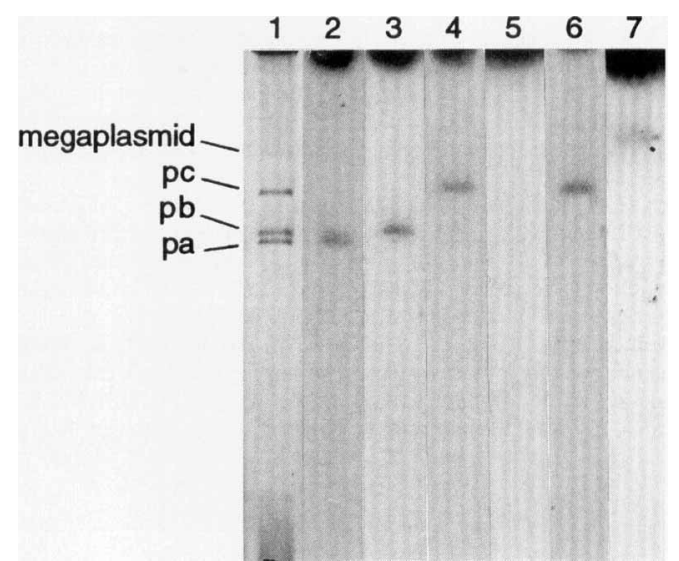

FIG. 3. Hybridization of plasmid profiles of $R$. tropici CFN299 with different probes. $E$. coli plasmids were purified by using a slightly modified alkaline lysis procedure. In most cases whole plasmids were used as probes; the only exception was $\mathrm{pEX} 80$. An 8-kb EcoRI fragment containing the exoF gene was purified from a $1 \%$ agarose gel by using a Geneclean II kit (Bio101, Inc., Vista, Calif.). Lane 1, ethidium bromide-stained Eckhardt gel; lanes 2 through 4, Southern blots of the plasmid profile hybridized with purified strain CFN299 plasmid probes (lane 2 , plasmid a; lane 3, plasmid b; lane 4, plasmid c); lanes 5 to 7, Southern blot of the plasmid profile hybridized with a 300-bp fragment of $R$. etli CFN42 16S ribosomal DNA (lane 5), with nifHDK genes from pCQ15 (lane 6), and with the exoF gene from pEX80 (lane 7). pc, plasmid c; pb, plasmid b; pa, plasmid a. 
quences clearly distinguished $R$. tropici type A strains from type B strains (36). Likewise, we found that while both types of strains harbor megaplasmids that are structurally conserved in strains belonging to the same subgroup, there is no overall homology between the megaplasmids in members of the two subgroups. The megaplasmids are therefore subgroup specific. The subgroup specificity of the megaplasmids represents a new finding for this species. This additional difference between the two subgroups could support the proposal that in the future taxonomists should define these two groups as subspecies or even different species, as originally proposed by Martínez et al. (17) and more recently by van Berkum et al. (36).

We are very grateful to D. Romero, S. Brom, M. L. Girard, and A. Eparvier for helpful discussions and to M. A. Moreno for technical assistance.

This work was supported in part by a grant from DGAPA, Universidad Nacional Autónoma de México.

\section{REFERENCES}

1. Amarger, N., M. Bours, F. Revoy, M. R. Allard, and G. Laguerre. 1994. Rhizobium tropici nodulates field-grown Phaseolus vulgaris in France. Plant Soil 161:147-156.

2. Cava, J. R., P. M. Elias, D. A. Turowski, and K. D. Noel. 1989. Rhizobium leguminosarum CFN42 genetic regions encoding lipopolysaccharide structures essential for complete nodule development on bean plants. J. Bacteriol. 171:8-15.

3. Crow, V. L., B. D. W. Jarvis, and R. M. Greenwood. 1981. Deoxyribonucleic acid homologies among acid-producing strains of Rhizobium. Int. J. Syst. Bacteriol. 31:152-172

4. Eckhardt, T. 1978. A rapid method for the identification of plasmid desoxyribonucleic acid in bacteria. Plasmid 1:584-588.

5. Finan, T. M. 1988. Genetic and physical analyses of group $\mathrm{E}$ exo- mutants of Rhizobium meliloti. J. Bacteriol. 170:474-477.

6. Finan, T. M., B. Kunkel, G. F. DeVos, and F. R. Signer. 1986. A second symbiotic megaplasmid in Rhizobium meliloti encodes exopolysaccharide and thiamine genes. J. Bacteriol. 167:66-72.

7. Finan, T. M., I. Oresnik, and A. Bottacin. 1988. Mutants of Rhizobium meliloti defective in succinate metabolism. J. Bacteriol. 170:3396-3403.

8. Flores, M., V. González, M. A. Pardo, A. Leija, E. Martínez, D. Romero, D. Piñero, G. Dávila, and R. Palacios. 1988. Genomic instability in Rhizobium phaseoli. J. Bacteriol. 170:1191-1196.

9. Graham, P. H., S. E. Viteri, F. Mackie, A. A. T. Vargas, and R. Palacios 1982. Variation in acid soil tolerance among strains of Rhizobium phaseoli. Field Crops Res. 5:121-128.

10. Hynes, M. F. 1993. Personal communication.

11. Hynes, M. F., R. Simon, P. Müller, K. Niehaus, M. Labes, and A. Pühler 1986. The two megaplasmids of Rhizobium meliloti are involved in the effective nodulation of alfalfa. Mol. Gen. Genet. 202:356-362.

12. Johnston, A. W. B., J. L. Beynon, A. V. Buchanan-Wollaston, S. M. Setchell, P. R. Hirsch, and J. E. Beringer. 1978. High frequency transfer of nodulating ability between strains and species of Rhizobium. Nature (London) 276:634636.

13. Keyser, H. H., B. Ben Bohlool, T. S. Hu, and D. F. Weber. 1982. Fast-growing rhizobia isolated from root nodules of soybean. Science 215:1631-1632.

14. Laguerre, G., M. P. Fernandez, V. Edel, P. Normand, and N. Armarger. 1993. Genomic heterogeneity among French Rhizobium strains isolated from Phaseolus vulgaris L. Int. J. Syst. Bacteriol. 43:761-767.

15. Leigh, J. A., J. W. Reed, J. F. Hanks, A. M. Hirsh, and G. C. Walker. 1987. Rhizobium meliloti mutants that fail to succinylate their calcofluor-binding exopolysaccharide are defective in nodule invasion. Cell 51:579-587.

16. Martínez, E., R. Palacios, and F. Sánchez. 1987. Nitrogen-fixing nodules induced by Agrobacterium tumefaciens harboring Rhizobium phaseoli plasmids. J. Bacteriol. 169:2828-2834.

17. Martínez, E., M. A. Pardo, F. Martins, P. Graham, A. Franco, R. Palacios, and L. Segovia. 1990. Genetic relatedness and taxonomic considerations of Rhizobium strains that nodulate Phaseolus vulgaris (L.), p. 831. In P. M. Gresshoff, L. E. Roth, G. Stacey, and W. E. Newton (ed.), Nitrogen fixation: achievements and objectives. Chapman and Hall, New York.

18. Martínez-Romero, E. 1994. Recent developments in Rhizobium taxonomy. Plant Soil 161:11-20.

19. Martínez-Romero, E., L. Segovia, F. M. Mercante, A. A. Franco, P. Graham, and M. A. Pardo. 1991. Rhizobium tropici, a novel species nodulating Phaseolus vulgaris L. beans and Leucaena sp. trees. Int. J. Syst. Bacteriol. 41:417 426.

20. Masterson, R. V., R. K. Prakash, and A. G. Atherly. 1985. Conservation of symbiotic nitrogen fixation gene sequences in Rhizobium japonicum and Bradyrhizobium japonicum. J. Bacteriol. 163:21-26.

21. Milner, J. L., R. S. Araujo, and J. Handelsman. 1992. Molecular and symbiotic characterization of exopolysaccharide-deficient mutants of Rhizobium tropici strain CIAT899. Mol. Microbiol. 6:3137-3147.

22. Noël, K. D., A. Sánchez, L. Fernández, J. Leemans, and M. A. Cevallos. 1984 Rhizobium phaseoli symbiotic mutants with transposon Tn5 insertions. J. Bacteriol. 158:148-155.

23. Nour, S. M., M. P. Fernández, P. Normand, and J. C. Cleyet-Marel. 1994 Rhizobium ciceri sp. nov., consisting of strains that nodulate chickpeas (Cicer arietinum L.). Int. J. Syst. Bacteriol. 44:511-522.

24. Novikova, N., and V. Safronova. 1992. Transconjugants of Agrobacterium radiobacter harbouring sym genes of Rhizobium galegae can form an effective symbiosis with Medicago sativa. FEMS Microbiol. Lett. 93:261-268.

25. Nuti, M. P., A. M. Ledeboer, A. A. Lepidi, and R. A. Schilperoort. 1977. Large plasmids in different Rhizobium species. J. Gen. Microbiol. 100:241248 .

26. O'Connell, K. P., and J. Handelsman. 1993. Foliar chlorosis in symbiotic host and nonhost plants induced by Rhizobium tropici type B strains. Appl. Environ. Microbiol. 59:2184-2189.

27. Pardo, M. A., J. Lagúnez, J. Miranda, and E. Martínez. 1994. Nodulating ability of Rhizobium tropici is conditioned by a plasmid-encoded citrate synthase. Mol. Microbiol. 11:315-321.

28. Prakash, R. K., and A. G. Atherly. 1986. Plasmids of Rhizobium and their role in symbiotic nitrogen fixation. Int. Rev. Cytol. 104:1-24.

29. Priefer, U. B. 1989. Genes involved in lipopolysaccharide production and symbiosis are clustered on the chromosome of Rhizobium leguminosarum bv. viciae VF39. J. Bacteriol. 171:6161-6168.

30. Quinto, C., H. de La Vega, M. Flores, L. Fernández, T. Ballado, G. Soberón, and R. Palacios. 1982. Reiteration of nitrogen fixation gene sequences in Rhizobium phaseoli. Nature (London) 229:724-726.

31. Rigby, P. W. J., M. Dieckmann, C. Rhodes, and P. Berg. 1977. Labelling deoxyribonucleic acid to a high specific activity in vitro by nick translation with DNA polymerase I. J. Mol. Biol. 113:237-251.

32. Rosenberg, C., P. Boistard, J. Dénarié, and F. Casse-Delbart. 1981. Genes controlling early and late functions in symbiosis are located on a megaplasmid in Rhizobium meliloti. Mol. Gen. Genet. 184:326-333.

33. Sambrook, J., E. F. Fritsch, and T. Maniatis. 1989. Molecular cloning: a laboratory manual, 2nd ed. Cold Spring Harbor Laboratory, Cold Spring Harbor, N.Y.

34. Segovia, L., D. Piñero, R. Palacios, and E. Martínez-Romero. 1991. Genetic structure of a soil population of nonsymbiotic Rhizobium leguminosarum. Appl. Environ. Microbiol. 57:426-433.

35. Simon, R. 1984. High frequency mobilization of gram-negative bacterial replicons by the in vitro constructed Tn 5 -mob transposon. Mol. Gen. Genet. 196:413-420.

36. van Berkum, P., R. B. Navarro, and A. A. T. Vargas. 1994. Classification of the uptake hydrogenase-positive ( $\mathrm{Hup}^{+}$) bean rhizobia as Rhizobium tropici. Appl. Environ. Microbiol. 60:554-561.

37. Wheatcroft, R., D. G. McRae, and R. W. Miller. 1990. Changes in the Rhizobium meliloti genome and the ability to detect supercoiled plasmids during bacteroid development. Mol. Plant Microbe Interact. 3:9-17. 